\title{
ATP-Activated Channels in Rat and Bullfrog Sensory Neurons: Concentration Dependence and Kinetics
}

\author{
Bruce P. Bean \\ Department of Neurobiology, Harvard Medical School, Boston, Massachusetts 02115
}

The concentration dependence and kinetics of ionic currents activated by extracellular adenosine 5 '-triphosphate (ATP) were studied in voltage-clamped dorsal root ganglion neurons from rats and bullfrogs. About $\mathbf{4 0} \%$ of neurons of both species responded to ATP with an increase in membrane conductance. The ATP-activated currents were similar in the 2 species, except that currents in rat neurons desensitized faster. In bullfrog neurons, the conductance was half-maximally activated by about $3 \mu \mathrm{M}$ ATP; at low concentrations, the conductance increased 3 - to 7 -fold for a doubling in [ATP], suggesting that several ATP molecules must bind in order to activate the current. A steeper concentration-response relationship than expected from 1:1 binding was also seen in rat neurons. The current activated quickly upon application of ATP and decayed quickly when ATP was removed. Activation kinetics were faster at higher [ATP], with time constants decreasing from about $200 \mathrm{msec}$ at $0.3 \mu \mathrm{M}$ ATP to about $10 \mathrm{msec}$ at $100 \mu \mathrm{M}$ ATP. Deactivation kinetics $(\tau \sim$ 100-200 msec) were independent of the ATP concentration. The rapid activation and deactivation make it seem likely that the ATP-activated current is mediated by direct ligand binding rather than by a second-messenger system. The experimental observations can be mimicked by a simple model in which ATP must bind to 3 identical, noninteracting sites in order to activate a channel. The potency and kinetics of ATP action were voltage-dependent, with hyperpolarization slowing deactivation and increasing ATP's potency. Deactivation kinetics were also sensitive to the concentration of external $\mathrm{Ca}$, becoming faster in higher $\mathrm{Ca}$.

There is increasing evidence that adenosine 5'-triphosphate (ATP) plays a role as an extracellular chemical messenger, probably even as a true neurotransmitter (see Burnstock, 1979; Stone, 1981; Su, 1983; Gordon, 1986). So far, the best cvidence for ATP as a synaptic transmitter has come from studies on sympathetic transmission to smooth muscle targets in various blood vessels and the vas deferens, where exogenously applied ATP can mimic the effect of nerve stimulation and structural analogs of ATP can inhibit the excitatory junction potential (Sneddon et al., 1982; Sneddon and Burnstock, 1984; Sneddon and Westfall, 1984).

\footnotetext{
Received Jan. 17, 1989; revised June 13, 1989; accepted June 21, 1989.
}

Thanks to Paul Ceelen for expert help in preparing cells and electrodes. Supported by grants from the NIH (HL-35034), the Rita Allen Foundation, and an Established Investigator Award from the American Heart Association.

Correspondence should be addressed to Bruce P. Bean, Department of Neurobiology, Harvard Medical School, 220 Longwood Avenue, Boston, MA 02115. Copyright (C) 1990 Society for Neuroscience $0270-6474 / 90 / 010001-10 \$ 02.00 / 0$
In neurons, a physiological role of ATP as a transmitter remains to be shown. However, such a role is plausible. Subsets of sensory neurons and spinal neurons can be excited by externally applied ATP (Jahr and Jessel, 1983; Salt and Hill, 1983; Fyffe and Perl, 1984). In studies on voltage-clamped neurons from cat and rat sensory ganglia, Krishtal and coworkers (1983) discovered that, in a subset of cells, ATP at micromolar concentrations activates a large conductance that is cation-permeable and reverses near $0 \mathrm{mV}$; it seems likely that this conductance underlies ATP's excitatory effects. More recently, ATP-activated currents have been found in smooth muscle cells from blood vessels (Benham and Tsien, 1987; Benham et al., 1987) and from the vas deferens (Nakazawa and Matsuki, 1987; Friel, 1988), in cardiac atrial cells (Friel and Bean, 1988), and in cultured skeletal muscle (Hume and Honig, 1986). In most of these muscle cells, as in sensory neurons, the predominant current activated by ATP is an excitatory, cation-permeable current that reverses near $0 \mathrm{mV}$. However, it already seems clear that the channels found in the various cell types are not identical, with differences in current-voltage relationships, cation selectivity, ligand selectivity, and single-channel properties (for review, see Bean and Friel, 1989).

The purpose of the work described in this and the following paper (Bean et al., 1990) was to further characterize ATP-activated currents in sensory neurons, with the particular goals of determining the kinetics of channel activation and deactivation and of recording currents through single channels. In this paper, I describe the concentration dependence of ATP activation of current in freshly dissociated bullfrog and rat dorsal root ganglion (DRG) neurons, which leads to the conclusion that channel activity is controlled by a receptor with 3 or more binding sites for ATP. In experiments with rapid application and removal of ATP, it was found that both activation and deactivation of channels occur within 10s-100s of milliseconds. The concentration-response and kinetic data are combined to construct a simple model of ATP-operated channels that assumes 3 ATP molecules must bind to activate a channel, with binding occurring at a rate typical for ligand binding to a selective receptor. The ability of this model to account for the experimental results suggests that ATP binding most likely activates channels directly, without an intervening second-messenger system. In the following paper, experiments on the current-voltage relationship, ionic selectivity, and single-channel behavior of ATP-activated channels are presented.

\section{Materials and Methods}

Preparation of cells. All experiments were done using freshly dissociated cell bodies to avoid complications arising from loss of voltage control in neurites of cultured cells. DRG were removed from adult bullfrogs 
(Rana catesbiana) and placed in oxygenated Ca-free Ringer's solution [in mM: $100 \mathrm{NaCl}, 2.5 \mathrm{KCl}, 5 \mathrm{MgCl}_{2}, 10$ glucose, 10 HEPES, pH 7.4]. The connective tissue sheath and calcareous mass were removed and the neural tissue was minced with scissors. The minced pieces were incubated at $35^{\circ} \mathrm{C}$ with $1 \mathrm{mg} / \mathrm{ml}$ collagenase (Cooper-Worthington or Sigma Type I) and $5 \mathrm{mg} / \mathrm{ml}$ Dispase (Boehringer-Mannheim) in $10 \mathrm{ml}$ of Ca-free Ringer's. After a 30 min incubation with gentle stirring, the pieces were transferred to a solution of $5 \mathrm{mg} / \mathrm{ml} \mathrm{Dispase}$ alone in $\mathrm{Ca}$ free Ringer's and incubated further, this time at $22^{\circ} \mathrm{C}$; the pieces were triturated about every $15 \mathrm{~min}$ with a broken-off Pasteur pipette until a reasonable density of single cells was visible in drops examined under a microscope.

$D R G$ cells from young rats (5-12 d postnatal) were isolated by the same protocol, except that the dissection and dispersion were done with Ca-free Tyrode's solution (in $\mathrm{mm}$ ): $150 \mathrm{NaCl}, 4 \mathrm{KCl}, 2 \mathrm{MgCl}_{2}, 10$ HEPES, 10 glucose, $\mathrm{pH} 7.4$ ). After isolation, both bullfrog and rat cells were diluted into Ca-free Tyrode's solution and stored at $5^{\circ} \mathrm{C}$ (bullfrog) or $22^{\circ} \mathrm{C}$ (rat) until use.

Solutions and electrical recording. Cells were voltage-clamped using patch pipettes (Hamill et al., 1981). Pipettes (Boralex glass, Rochester Scientific Co., Rochester, NY) had resistances of $1-25 \mathrm{M} \Omega$, with lowerresistance electrodes and series resistance compensation used when it was important to minimize series resistance errors (as in the experiments shown in Fig. 10) or to maximize the frequency response (as in the noise-analysis experiments described in the next paper). The pipettes were filled with 1 of 3 internal solutions: "K-glutamate," consisting of (in mM) $120 \mathrm{~K}$ glutamate, $5 \mathrm{MgCl}_{2}, 10$ EGTA, 10 HEPES, $\mathrm{pH}$ adjusted to 7.4 with $\mathrm{KOH}$; "Cs-glutamate," consisting of $120 \mathrm{Cs}$ glutamate, 5 $\mathrm{MgCl}_{2}, 10$ EGTA, 10 HEPES, pH adjusted to 7.4 with $\mathrm{CsOH}$; "Mgfree Cs-glutamate," consisting of 140 Cs glutamate, 10 EGTA, 10 HEPES, $\mathrm{pH}$ adjusted to 7.4 with $\mathrm{CsOH}$.

Unless otherwise noted, the external solution was " $2 \mathrm{Ca}$ Tyrode's," consisting of (in mM) $2 \mathrm{CaCl}_{2}, 150 \mathrm{NaCl}, 4 \mathrm{KCl}, 2 \mathrm{MgCl}_{2}, 10$ glucose, and 10 HEPES, pH adjusted to 7.4 with $\mathrm{NaOH}$. ATP was added as the $\mathrm{Na}$ salt, and ATP-containing solutions were prepared daily, either from fresh powder or from stock aliquots $(100 \mathrm{~mm}) \mathrm{kept}$ at $-70^{\circ} \mathrm{C}$. ATPcontaining solutions were kept on ice until use to minimize hydrolysis. For ATP concentrations $>100 \mu \mathrm{M}$, the $\mathrm{pH}$ of the solution was readjusted after addition of ATP. This was important since the bullfrog DRG neurons, as well as the rat neurons, generated currents in response to decreases in the $\mathrm{pH}$ of the external solution, as originally described by Krishtal and Pidoplichko (1980).

After establishing a whole-cell recording, the cell was lifted off the bottom of the chamber and placed in front of one of a series of 10 microcapillary tubes (internal diameter, $145 \mu \mathrm{m}$ ) into which solutions flowed from reservoirs $\sim 50 \mathrm{~cm}$ above. Rapid solution changes were made by abruptly moving the pipette between the mouths of 2 capillaries using a coarse micromanipulator. The speed of the solution changes are dependent on the geometry of the cell and the abruptness of its movement; when cells were transferred between different bathing solutions, holding currents changed with time constants of 6-15 msec (e.g., Fig. $7 B$ ). There is no marker of the exact instant of the solution change; however, direct monitoring of oscilloscope records during solution changes showed no obvious delay in the rise or fall of current during a solution change, so the bars on the figures showing the time of ATP application, which are drawn to correspond to the first detectable deflection of the current record, are probably good approximations.

Currents were recorded with a List EPC7 patch-clamp amplifier (Medical Systems Corp., Greenvale, NY). Currents were low-pass-filtered either with the $3 \mathrm{KHz}(-3 \mathrm{~dB}) 3$-pole Bessel filter built into the amplifier or with an external filter set at corner frequencies of $1-10 \mathrm{kHz}(-3 \mathrm{~dB}$, 8-pole Bessel). Currents were digitized (usually at $5 \mathrm{kHz}$ ) and stored on a laboratory computer. In most cases, currents were also digitized and stored on videotape using a pulse-code modulator/video casette recorder system (Dagan Instruments, Minneapolis, MN) for later analysis.

Membrane potentials were corrected for 2 junction potentials. One is between the internal (pipette) solution and the Tyrode's solution in which the pipette current was zeroed before sealing onto a cell; this was near $-10 \mathrm{mV}$ for all 3 glutamate-containing internal solutions (pipette negative), and this value was added to the nominal membrane potentials. The second was between the external solution (flowing from the microcapillary tube) bathing the cell and the Tyrode's solution in the experimental chamber. This potential was $-7 \mathrm{mV}$ with the isotonic $\mathrm{CaCl}_{2}$ (Fig. 11 of this paper and Fig. 5 of the following paper) and +10 $\mathrm{mV}$ with the $\mathrm{Mg}$-free Cs-glutamate solution (fig. $2 D$ of the following paper); these potentials (external solution minus Tyrode's) were added to the nominal membrane potential. This second junction potential was only $-1 \mathrm{mV}$ with either the $160 \mathrm{mM} \mathrm{NaCl}, 2 \mathrm{mM} \mathrm{CaCl}_{2}$ solution or the $160 \mathrm{~mm} \mathrm{NaC1}, 0.1 \mathrm{~mm}$ EDTA solution (Fig. 11) and was ignored in these cases.

With the exception of that shown in Figure $9 B$ of the following paper, all experiments were done at room temperature $\left(21-24^{\circ} \mathrm{C}\right)$.

All statistics are given as means \pm SEM.

\section{Results}

Figure 1 shows current elicited by rapid application of ATP to rat and bullfrog DRG neurons. In cells from both species, with normal Tyrode's solution externally, ATP elicited an inward current at a holding potential of $-80 \mathrm{mV}$. The inward current activated quickly upon application of the ATP and decayed quickly upon its removal. Only a minority of the DRG neurons tested responded with ATP-activated current: 80 of 206 bullfrog neurons and 24 of 56 rat neurons gave detectable whole-cell responses. In the experiments in this and the following paper, we generally selected small (20- to $35-\mu \mathrm{m}$-diameter) bullfrog neurons for testing, since early experiments gave us the impression that few large cells were responsive to ATP, but this point was not examined systematically. We also chose small rat neurons (16-26 $\mu \mathrm{m}$ in diameter) for testing.

In sensitive bullfrog neurons, the current activated by $100 \mu \mathrm{M}$ ATP recorded at $-80 \mathrm{mV}$ with an external solution of either 2 Ca Tyrode's or $160 \mathrm{~mm} \mathrm{NaCl}, 2 \mathrm{~mm} \mathrm{CaCl}_{2}, 10 \mathrm{~mm}$ HEPES (pH 7.4 with $\mathrm{NaOH}$ ) ranged from $-30 \mathrm{pA}$ to $-9 \mathrm{nA}$, with mean of $-1935 \mathrm{pA}( \pm 295 \mathrm{pA}, n=51)$. In rat neurons, the current ranged from $-70 \mathrm{pA}$ to $-3.5 \mathrm{nA}$, with a mean of $-860 \mathrm{pA}$ $( \pm 260 \mathrm{pA}, n=13)$.

In all bullfrog neurons and most rat neurons, $1 \mu \mathrm{M} \mathrm{ATP} \mathrm{ac-}$ tivated a current that was maintained steadily during applications lasting 2-10 sec. However, in both species application of concentrations of $10 \mu \mathrm{M}$ or higher resulted in currents that decayed during the maintained presence of ATP. In a given neuron, this desensitization was faster with higher ATP concentrations. As illustrated by the typical responses in Figure 1, desensitization was much faster in rat neurons than frog neurons. With $100 \mu \mathrm{M} \mathrm{ATP,} \mathrm{currents} \mathrm{in} \mathrm{most} \mathrm{bullfrog} \mathrm{neurons}$ declined only $10-20 \%$ in applications lasting $10 \mathrm{sec}$ or so, while currents in rat neurons typically declined by $50 \%$ or more with $10 \mathrm{sec}$ applications of $100 \mu \mathrm{M}$ ATP. The difference in desensitization kinetics was the major difference between ATP responses of bullfrog and rat neurons. As previously reported by Krishtal et al. (1983), the recovery from desensitization was slow, taking many minutes, and recovery was usually incomplete. For this reason, bullfrog neurons were better suited for experiments where desensitization raised problems, such as concentration-response studies, noise analysis, and single-channel recordings.

\section{Contrast between $A C h$ and $A T P$ responses}

In some skeletal muscle preparations, ATP has been reported to activate channels that are similar or identical to those activated by acetylcholine (ACh) (Kolb and Wakelam, 1983; Igusa, 1989; but see Hume and Honig, 1986), raising the possibility that ATP may be capable of activating some types of nicotinic $\mathrm{ACh}$ receptor channels. It was therefore of interest to see if sensory neurons responding to ATP also possessed ACh receptors. In most of the tested bullfrog DRG neurons, ACh did elicit sizable currents, and many of these neurons also gave currents 
A Rat

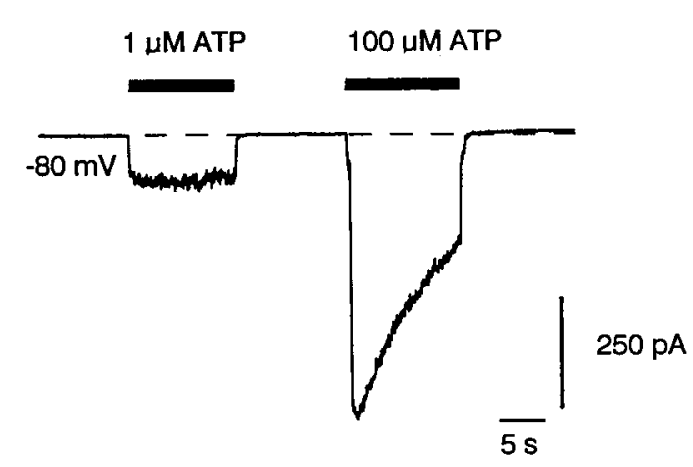

B Frog

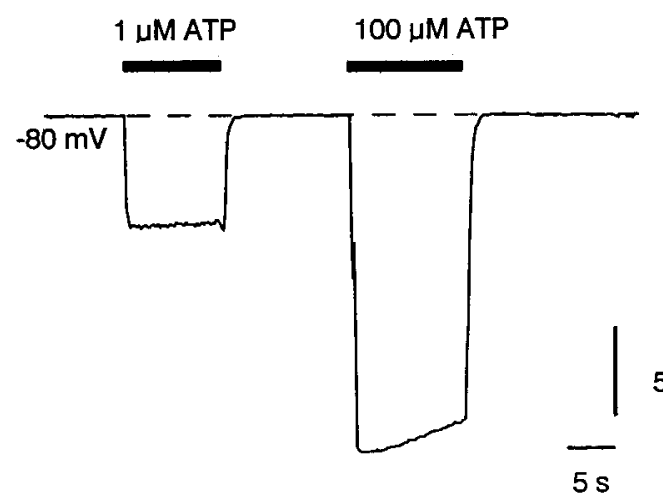

Figure 1. ATP-activated currents in dorsal root ganglion neurons. $A$, Currents activated by 1 and $100 \mu \mathrm{M}$ ATP in a neuron from a 10-d-old rat. K-glutamate internal solution. Filtered at $1 \mathrm{kHz}$. Cell W16C; diameter, $20 \mu \mathrm{m}$. $B$. Currents in a neuron from an adult bullfrog. Csglutamate internal solution. Filtered at $5 \mathrm{kHz}$. Cell W20C; diameter, $36 \mu \mathrm{m}$.

in response to ATP. However, in contrast to the currents activated by $A T P$, the currents elicited by $\mathrm{ACh}$ invariably desensitized within several seconds (Fig. $2 A$ ). More tellingly, several cells gave large currents in response to $\mathrm{ACh}$ but had no response to ATP (e.g., Fig. $2 B$ ), strongly suggesting that different receptors underlie the 2 responses. Of 14 bullfrog DRG neurons tested with both ATP $(100 \mu \mathrm{M})$ and ACh $(200 \mu \mathrm{M}), 7$ responded to both $A T P$ and $A C h, 3$ responded to neither, and 4 responded to ACh but not ATP.

\section{Concentration-response}

Figure 3 shows a concentration-response curve constructed from collected data from bullfrog neurons. Although individual cells showed variable sensitivity, $0.3 \mu \mathrm{M}$ ATP almost always elicited detectable current and 1-10 $\mu \mathrm{M}$ ATP was usually about half as effective as $100 \mu \mathrm{M}$. ATP at $600 \mu \mathrm{M}$ elicited only slightly $(\sim 15 \%$, on the average) more current than $100 \mu \mathrm{M}$. The collected data could be fit moderately well by a curve corresponding to $1: 1$ binding with a $K_{d}$ of about $3 \mu \mathrm{M}$. Rat neurons had a similar sensitivity, with $1 \mu \mathrm{M}$ ATP evoking $27 \pm 4 \%(n=6)$ of the current evoked by $100 \mu \mathrm{M}$, compared with $34 \pm 4 \%(n=17)$ in bullfrog neurons. The potency of ATP in rat neurons fits well with the $K_{d}$ of $5 \mu \mathrm{M}$ reported for a rat neuron studied by Krishtal et al. (1983).

Although the collected data from bullfrog neurons were fit
A

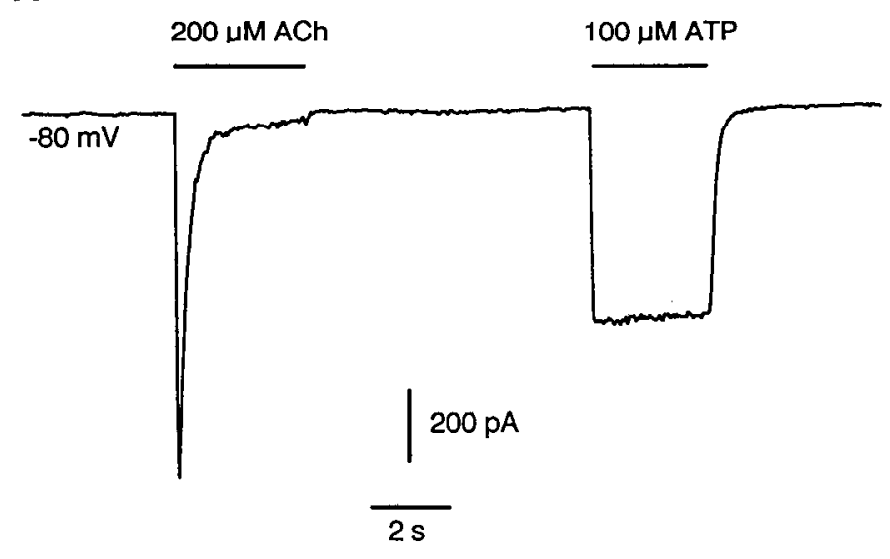

B

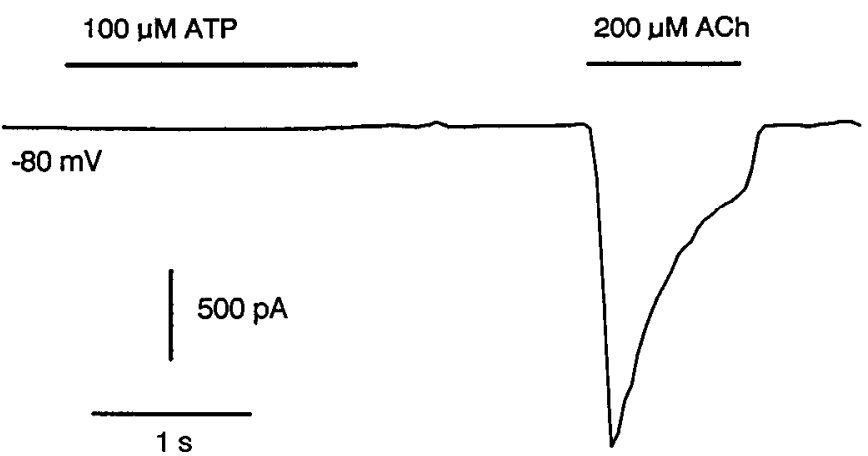

Figure 2. Comparison of responses to ACh and ATP in 2 bullfrog DRG neurons. $A$, Currents elicited by $200 \mu \mathrm{M} \mathrm{ACh}$ and $100 \mu \mathrm{M}$ ATP in a neuron that responded to both. Cell K15E, $25 \mu \mathrm{m}$. $B$, Currents in a neuron that responded to ACh but not ATP. The indicated time of application of ATP is approximate. The cell passed briefly $(<0.5 \mathrm{sec})$ through a solution containing $1 \mu \mathrm{M}$ ATP in between the application of $100 \mu \mathrm{M}$ ATP and $200 \mu \mathrm{M}$ ACh. Cell K20A, $27 \mu \mathrm{m}$. In both cells, the internal solution was $\mathrm{Mg}$-free $\mathrm{Cs}$ glutamate and the external solution was $160 \mathrm{~mm} \mathrm{NaCl}, 2 \mathrm{mM} \mathrm{CaCl}$, and $10 \mathrm{~mm}$ HEPES (pH 7.4 with $\mathrm{NaOH})$.

moderately well by a curve drawn for 1:1 binding, there was a systematic deviation at low ATP concentrations, where the actual responses rose more steeply than predicted by theory. Since a superlinear concentration-response relationship would suggest that multiple ligand molecules must bind in order to open channels, the response to low concentrations of ATP was studied more carefully in individual cells. Figure 4 shows an example: a bullfrog DRG neuron was exposed sequentially to concentrations of ATP ranging from 0.3 to $10 \mu \mathrm{M}$, bracketed by exposures to $100 \mu \mathrm{M}$ ATP. As shown by the similarity of the responses in the ascending and descending series of concentrations, and the similarity of the before and after responses to $100 \mu \mathrm{M}$, there was little desensitization during the series. Of particular interest was the response to the lowest concentrations of ATP, shown at higher gain in Figure $4 B$. In this cell, which had an unusually low sensitivity to ATP, $0.3 \mu \mathrm{M}$ ATP elicited very little current (about $3 \mathrm{pA}$, subtracting the averaged current just before from that during the application). Doubling the concentration to 0.6 $\mu \mathrm{M}$ resulted in a large increase in the current, to $32 \mathrm{pA}$, and doubling the concentration again resulted in an increase to 224 


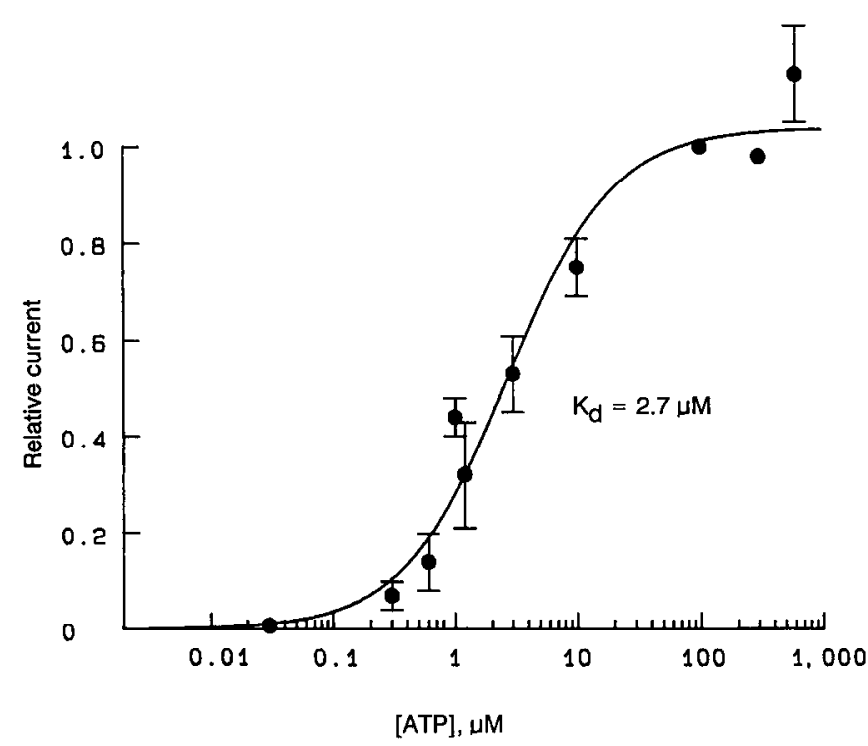

Figure 3. Collected concentration-response data from 25 bullfrog neurons. In each cell, currents elicited by various concentrations of ATP were normalized to that elicited by $100 \mu \mathrm{M}$ ATP, usually applied immediately afterward, as in Figure 1. Symbols represent means \pm SEM for determinations in different cells. Most determinations were made at a holding potential of $-80 \mathrm{mV}$, with a few at -70 or $-100 \mathrm{mV}$.

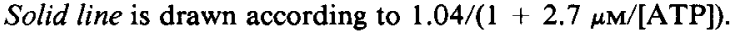

pA. The 7-fold increase in the current seen with a doubling of ATP from 0.6 to $1.2 \mu \mathrm{M}$ is clearly at odds with the expectations from 1:1 binding, which would predict that a doubling in ligand concentration would produce a doubling in current (or somewhat less, since a strictly linear relationship only holds for very low concentrations). A much steeper current-concentration relationship than predicted by 1:1 binding was seen in all cells tested using low ATP concentrations; collected results are shown in Table 1 . On average, a 5 -fold increase was seen for a doubling in ATP concentration in the range of 0.3-1.2 $\mu \mathrm{M}$. It is notable that the increase in current for a doubling of ATP in this range was highest in the 2 cells with the lowest sensitivity to ATP.

Figure 5 shows the concentration-response relationship for a single bullfrog neuron in which the response to a wide range of concentrations was measured. As expected from the results just discussed, the experimental response rises much more steeply at low ATP concentrations than predicted by a curve drawn according to $1: 1$ binding. The data at low [ATP] are considerably better fit by a curve drawn according to a simple model that assumes 3 ATP molecules must bind in order for a channel to open (Fig. 9). The model used to generate the dashed line in

Table 1. Concentration dependence at low ATP concentrations

\begin{tabular}{lcll} 
Cell & $\frac{I(0.6)}{I(0.3)}$ & $\frac{I(1.2)}{I(0.6)}$ & $\frac{I(0.6)}{I(100)}$ \\
\hline W33G & 3.5 & - & 0.25 \\
W33I & 3.4 & 2.5 & 0.18 \\
W33L & $\sim 10$ & 7.0 & 0.03 \\
W33K & 4.1 & 4.5 & 0.07 \\
& $5.2 \pm 1.8$ & $4.7 \pm 1.6$ & \\
\hline
\end{tabular}

All experiments were done with frog neurons using the conditions and protocol shown in Figure 4. Numbers in bottom row are means \pm SEM.
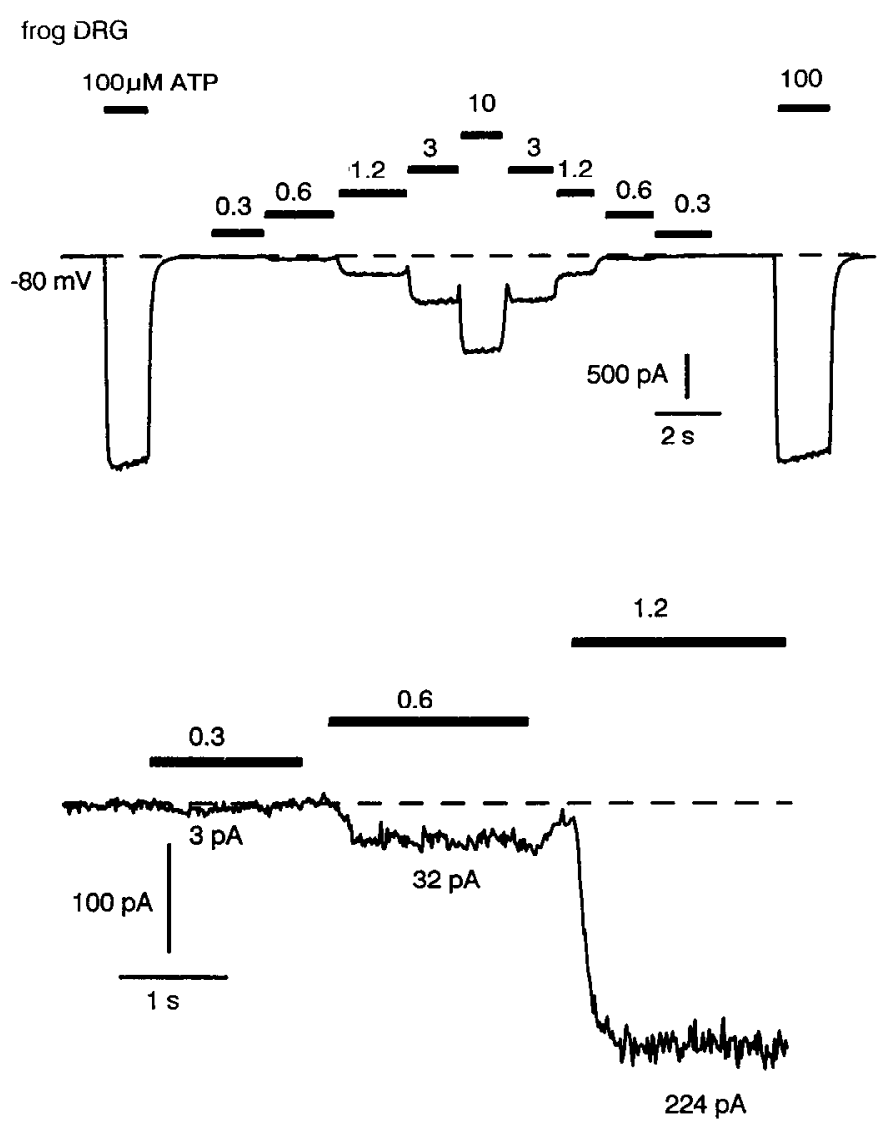

Figure 4. Current activated by low and high [ATP] in a bullfrog neuron. Top, Sequential application of ATP concentrations from 0.3 to $10 \mu \mathrm{M}$, bracketed by application of $100 \mu \mathrm{M}$. The sensitivity of this cell was unusually low, with $K_{1 / 2}>10 \mu \mathrm{M}$ (compare with Figs. 3, 5). Bottom, Current activated by $0.3,0.6$, and $1.2 \mu \mathrm{M}$ ATP at higher gain. Csglutamate internal solution. Filtered at $1 \mathrm{kHz}$. Cell W33L; diameter, 36 $\mu \mathrm{m}$.

Figure 5 is like that used by Colquhoun and Ogden (1988) to describe the concentration-response relationship for the nicotinic $\mathrm{ACh}$ receptor at the neuromuscular junction, except that the dose-response data for $\mathrm{ACh}$ receptor channels are consistent with 2:1 binding of ligand (see also Dionne et al., 1978; Chabala et al., 1986), while the results in Figure 4 and Table 1 suggest a minimum of 3:1 binding for the ATP-operated channel.

In drawing the theoretical curve in Figure 5, it was assumed (for simplicity) that binding of the 3 ATP molecules takes place with the same microscopic equilibrium constant (i.e., that there is no positive or negative cooperativity). Such a model predicts a Hill slope that is 3 at very low concentrations and declines to 1 at high concentrations [for discussion of such models, see Colquhoun and Ogden (1988)]; at higher concentrations, the shape of the predicted concentration-response relationship differs little from that of $1: 1$ binding. In this cell and several others in which complete concentration-response curves were obtained, there were systematic deviations from the theory at high concentrations; there were larger differences in the responses to 100 and $600 \mu \mathrm{M}$ ATP than predicted. It is possible that assuming some negative cooperativity in binding would provide a slightly better fit at high concentrations.

The deviation from 1:1 binding in the concentration-response relationship in bullfrog cells seemed surprising, since Krishtal et al. (1983) found that the concentration-response relationship 


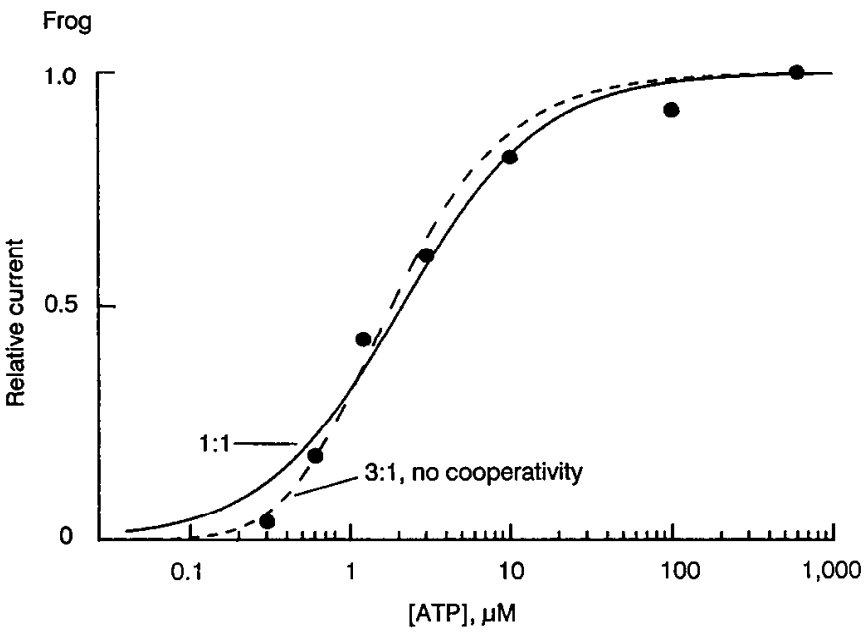

Figure 5. Concentration-response relationship determined in a single bullfrog neuron over a wide range of ATP concentrations. Concentrations of $0.3-600 \mu \mathrm{M}$ were applied, and the currents were normalized to that elicited by $600 \mu \mathrm{M}$ ATP (758 pA). Cs-glutamate solution. Cell W33I; diameter, $32 \mu \mathrm{m}$. Solid line is drawn according to $1 /(1+2.1 \mu \mathrm{M} /[$ ATP] $)$, the expected relationship with 1:1 ligand : receptor binding with a $K_{d}$ of $2.1 \mu \mathrm{M}$. Dashed line is drawn according to $G^{3}(1+\beta / \alpha) /\left[1+3 G+3 G^{2}\right.$ $\left.+G^{3}(1+\beta / \alpha)\right]$, where $G=[\mathrm{ATP}] / K_{\text {diss, }}$, with $K_{\text {diss }}$ (the microscopic dissociation constant, $k_{\text {off }} / k_{\text {on }}$ ) equal to $0.47 \mu \mathrm{M}$; the ratio $\beta / \alpha$ was set equal to $1 / 4$ to be consistent with the single-channel data in the next paper.

in a rat sensory neuron could be fit well by assuming a 1:1 stoichiometry. I therefore investigated this point in rat DRG neurons. It was difficult to define complete concentration-response curves in individual rat neurons because of poorly reversible desensitization with higher concentrations of ATP, even when applied for only 1 or 2 sec. However, in some cells low concentrations of ATP could be applied with relatively little desensitization. Figure 6 shows the response of such a rat DRG neuron to low concentrations of ATP. As in the case of bullfrog DRG cells, the response of rat DRG neurons to low ATP concentrations showed a clear superlinearity. In the cell shown in Figure 6, doubling the ATP concentration from 0.3 to $0.6 \mu \mathrm{M}$ resulted in a 2.9-fold enhancement of current. In a total of 6 rat DRG neurons studied using ATP concentrations in the range of $0.3-1.2 \mu \mathrm{M}$, doubling the ATP concentration resulted in an average $2.5 \pm 0.2$-fold enhancement of current. While the concentration-response relationship is a bit less steep than in bullfrog neurons, it is considerably steeper than predicted by $1: 1$ binding stoichiometry. These results suggest that in both bullfrog and rat neurons, the ATP-operated channels are controlled by receptors having multiple binding sites for ATP.

\section{Kinetics}

Both the rise of current on application of ATP and its fall on removal of ATP take place on a subsecond time scale. The rise time of the current was strongly dependent on the ATP concentration, while the rate of decline was not. Figure 7 shows typical results from an experiment in which high and low concentrations of ATP were applied to a bullfrog DRG neuron. Both the rise and fall of the current could be fit well by a single exponential. The time constant of the activation of current declined from $85 \mathrm{msec}$ at $1 \mu \mathrm{M}$ ATP to $8 \mathrm{msec}$ at $100 \mu \mathrm{M}$ ATP; however, the deactivation of current upon removal of ATP took place with a time constant of about $110 \mathrm{msec}$ in both cases. To

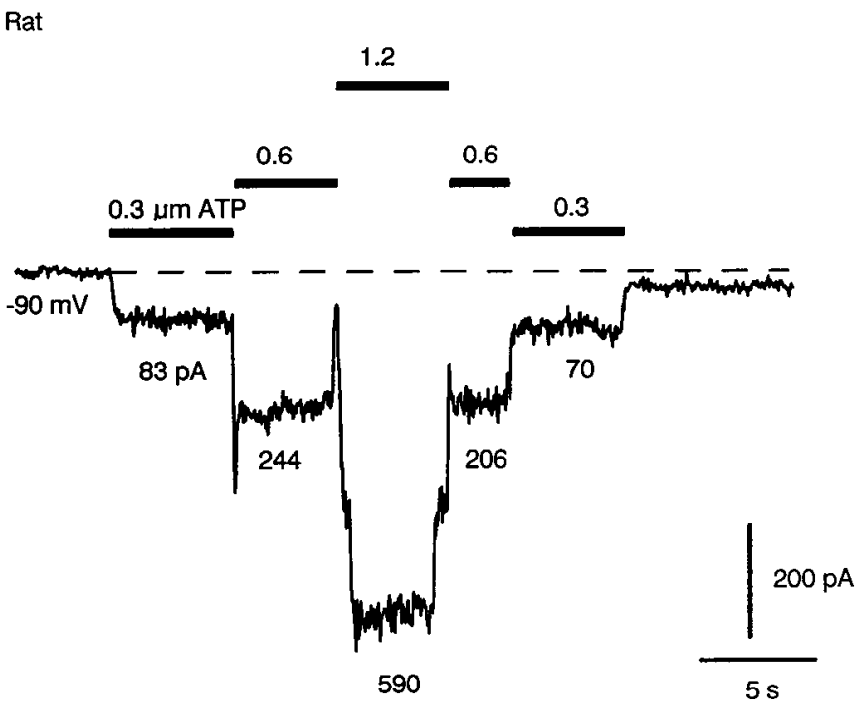

Figure 6. Response of a rat neuron to low concentrations of ATP. Numbers below the current segments give the current in pA; for the first applications of 0.3 and $0.6 \mu \mathrm{M}$, the initial baseline was used, and for the second applications, the baseline after washout was used. For the application of $1.2 \mu \mathrm{M}$, an average of the initial and final baselines was used. Cs-glutamate internal solution, $3 \mathrm{kHz}$ filtering. Cell W77D; diameter, $25 \mu \mathrm{m}$; 10-d-old rat.

define the time course of the solution change in this cell, the external solution was changed-in the continual presence of ATP - from normal Tyrode's solution to a solution in which $\mathrm{Na}$ was replaced by the large cation $N$-methyl-D-glucamine (which, as shown in the following paper, is virtually impermeant in the ATP-activated channel). The current declined rapidly upon removal of $\mathrm{Na}$, with a time constant of $9 \mathrm{msec}$ (Fig. $7 \mathrm{C}$ ). Thus, the solution changes are very fast compared with the deactivation of ATP-elicited current or the rise of current elicited by low ATP concentrations. However, the rise of current in response to $100 \mu \mathrm{M}$ ATP is comparable to the time course of the solution change. In fact, the rise of current induced by 100 $\mu \mathrm{M}$ ATP was often slightly faster than the rate of solution change, as expected from application of an agonist concentration 100 times higher than the half-maximal concentration.

There was considerable variability in the kinetics of ATPactivated current in different cells. The time constant for deactivation varied from 70 to $330 \mathrm{msec}$, with similar variability in the time course of activation by low ATP concentrations. In cells from a given preparation, there was less variation, usually a factor of 2 or less. Figure 8 shows collected results from 7 cells, all from the same bullfrog, in which the kinetics of current activated by different concentrations of ATP were compared. The time constant for activation of current fell from a mean of $171 \mathrm{msec}$ at $0.3 \mu \mathrm{M}$ ATP to $8 \mathrm{msec}$ at $100 \mu \mathrm{M}$ ATP. In contrast to the activation time constant, the decay time constant showed no systematic dependence on ATP concentration.

Both activation and deactivation were faster in rat neurons than in frog neurons. In 4 rat neurons in which 1 or $1.5 \mu \mathrm{M}$ ATP was applied, the mean time constant for the rise of the current was $50 \pm 12 \mathrm{msec}$, smaller than the value of $124 \pm 16 \mathrm{msec}$ obtained in bullfrog neurons with $1 \mu \mathrm{M} \operatorname{ATP}(n=12)$. The time course of deactivation was also different between the 2 species, with the average time constant in rat neurons $(78 \pm 11 \mathrm{msec}$, $n=11$ ) being more than a factor of 2 smaller than in bullfrog 
A

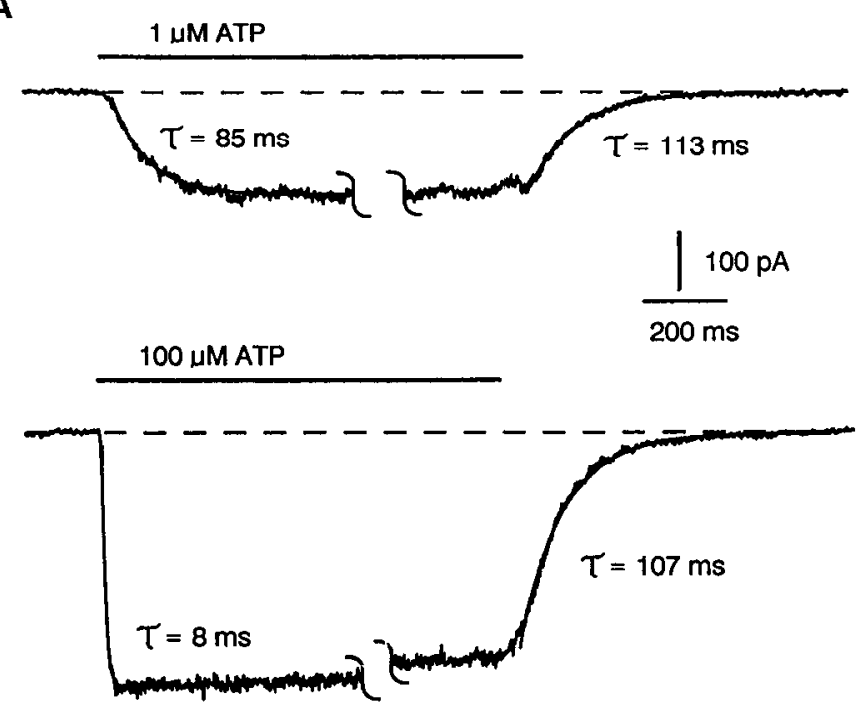

B

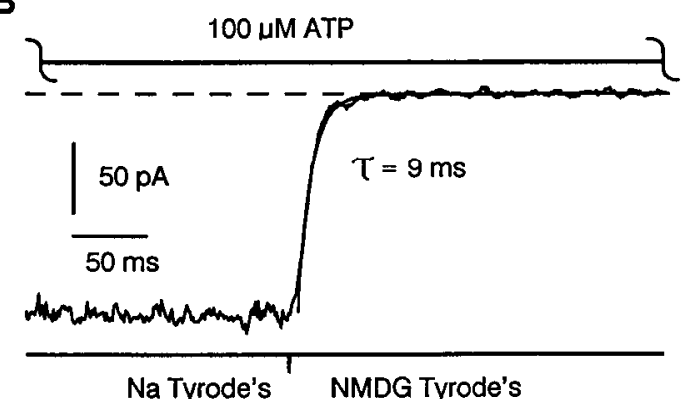

Figure 7. Kinetics of current activated by 1 or $100 \mu \mathrm{M}$ in a bullfrog DRG neuron. A, Top: Onset and recovery of current elicited by $1 \mu \mathrm{M}$ ATP. ATP was applied for $5.5 \mathrm{sec}$; the middle portion of current is omitted to save space. Bottom: Onset and recovery of current elicited by $100 \mu_{\mathrm{M}}$ ATP. Total duration of application was $2 \mathrm{sec}$. In both parts, solid lines superimposed on the experimental traces are best-fitting exponential curves. $B$ (same cell as for $A$ ), Time course of solution change determined by disappearance of the ATP-induced current upon replacement of Na by $N$-methyl-D-glucamine. The cell was abruptly transferred from normal Tyrode's solution containing $100 \mu \mathrm{M}$ ATP to the same solution but with $\mathrm{Na}$ replaced on an equimolar basis by NMDG (and also containing $100 \mu \mathrm{M}$ ATP). Cs-glutamate internal solution, $3 \mathrm{kHz}$ filtering. Cell $\mathrm{K} 14 \mathrm{H}, 22 \mu \mathrm{m}$.

neurons $(200 \pm 33 \mathrm{msec}, n=17)$. All these measurements were made at membrane potentials of -70 to $-80 \mathrm{mV}$.

Figure 9 shows a simple model for ATP activation of channels that is consistent with the experimental observations on kinetics and concentration dependence. The model is based on current kinetic models for the nicotinic ACh receptor channel (Colquhoun and Ogden, 1988). It is assumed that each channel possesses 3 identical binding sites for ATP, that all 3 sites must be occupied for a channel to be activated, and that binding to the 3 sites is independent (i.e., there is no cooperativity). Taking account of the single-channel behavior shown on the following paper, it is assumed that when all 3 binding sites are occupied, a channel flickers rapidly between an open and a closed state, spending only a fifth or so of its time in the open state.
Figure 9 shows that the model can reproduce the activation and deactivation kinetics of the ATP-activated current in bullfrog neurons quite well. In the model, the decay of current following removal of ATP proceeds with a rate constant of $3 k_{\text {or }}$ $[\alpha /(\alpha+\beta)]$. Using the mean time constant of decay that was determined in the set of experiments in Figure $8(104 \mathrm{msec})$, $k_{\text {off }}$ was set at $4 \mathrm{sec}^{-1}$. Then, $k_{\text {on }}$ was varied to see if there was a value which would give the activation kinetics experimentally observed at different ATP concentrations. It was found by trial and error that a $k_{\text {on }}$ of $1.2 \times 10^{7} \mathrm{M}^{-1} \mathrm{sec}^{-1}$ closely reproduced the activation kinetics at different ATP concentrations observed in Figures 7 and 8. As shown in Figure 9, the kinetics of the current predicted by the model can be well fit (after a short initial delay) by a single exponential, and the time constant of the exponential decreases with ATP concentration in a manner that closely matches that of the experimental data (Fig. 8). It should be noted that the exponential time course does not reflect any single rate-limiting step in the model; relaxation in a 5-state model like that in Figure 9 actually occurs with a time course given by the sum of 4 exponential terms, the time constant for each being (in general) a complicated function of all the rate constants. However, in many cases-especially when many of the rate constants are of similar magnitude-much of the relaxation may be nearly indistinguishable from a single exponential, as in Figure 9, without being limited by a particular step.

The values of $k_{\text {on }}$ and $k_{\text {off }}$ in Figure 9 were chosen solely to fit the kinetics of the current in the bullfrog neurons, without taking independent account of the concentration-response relationship. However, the value for the microscopic dissociation constant of ATP binding predicted from the model, $K_{\text {diss }}=k_{\text {off }} /$ $k_{\text {on }}=0.33 \mu \mathrm{M}$, is not far from the value of $0.47 \mu \mathrm{M}$ used to fit the concentration-response curve in Figure 3.

\section{Voltage dependence}

Both the potency of ATP and the rate of decay of current upon removal of ATP were found to depend on the membrane potential. Figure 10 shows current records from a cell in which 1 and $100 \mu \mathrm{M}$ ATP were applied at membrane potentials from +60 to $-120 \mathrm{mV}$. At $+60 \mathrm{mV}$, the current activated by $1 \mu \mathrm{M}$ ATP was about $20 \%$ of that activated by $100 \mu \mathrm{M}$, while at -120 $\mathrm{mV} 1 \mu \mathrm{M}$ ATP activated a current nearly $60 \%$ as large as that activated by $100 \mu \mathrm{M}$. This 3-fold change in ATP's potency was accompanied by changes in the time course of deactivation of the current, the time constant increasing from $60 \mathrm{msec}$ at +60 $\mathrm{mV}$ to $230 \mathrm{msec}$ at $-120 \mathrm{mV}$. In the context of a scheme for channel operation like that in Figure 9, an increase in the time constant for deactivation could arise from an equivalent decrease in the rate constant for unbinding of ATP. In the absence of other changes in rate constants, a decrease in the rate of unbinding predicts an increase in potency, as observed. In fact, the changes in potency and the deactivation kinetics can be quantitatively fit by the model in Figure 9 assuming that the only change produced by voltage is in the rate constant for unbinding of ATP (solid lines in Fig. 10B).

\section{Ca dependence of deactivation kinetics}

Deactivation kinetics were also found to depend on the concentration of $\mathrm{Ca}$ in the external solution. This effect became obvious during experiments to test the permeability of $\mathrm{Ca}$ in the channel, described in more detail in the next paper. When the $2 \mathrm{~mm}$ Ca usually present in the external solution was re- 


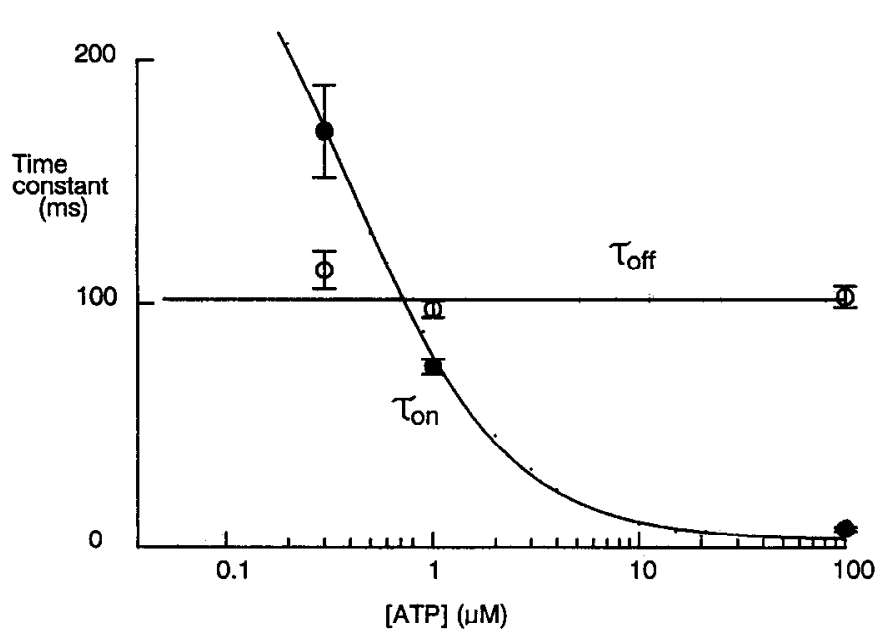

Figure 8. Average time constants for the onset and recovery of ATPactivated current in bullfrog neurons. The data were gathered from 7 cells from the same bullfrog. Symbols and error bars represent means \pm SEM for determinations in several cells at each ATP concentration. Values are as follows: $\tau_{o n}$ (filled circles): $0.3 \mu \mathrm{M}, 171 \pm 19$ (14 observations from 4 cells); $1 \mu \mathrm{M}, 75 \pm 3$ ( 16 observations from 6 cells); 100 $\mu \mathrm{M}, 8 \pm 1$ (16 observations from 7 cells). $\tau_{\text {off }}$ (open symbols): $0.3 \mu \mathrm{M}$, $114 \pm 8$ (14 observations from 4 cells); $1 \mu \mathrm{M}, 98 \pm 4$ (17 observations from 7 cells); $100 \mu \mathrm{M}, 103 \pm 5$ (17 observations from 7 cells). All determinations were done at a holding potential of $-80 \mathrm{mV}$. The solid line represents predictions of the model in Figure 9, determined by exponential fits to the currents simulated by the model.

moved (and $100 \mu \mathrm{M}$ EDTA added to chelate contaminating Ca), the decay of the current upon removal of ATP was strikingly slowed (Fig. 11 $\mathrm{A}$ ). Conversely, when the Ca level in the external solution was increased to $113 \mathrm{~mm}$ (by roughly equiosmolar replacement of $\mathrm{Na}$ ), the deactivation kinetics became substantially faster. Both effects were completely reversible upon returning to normal concentrations of $\mathrm{Ca}$. In combined results from 12 cells, the time constant of deactivation (measured at $-80 \mathrm{mV}$ ) fell from an average of about $600 \mathrm{msec}$ in $\mathrm{Ca}$-free solution to about $50 \mathrm{msec}$ in $113 \mathrm{~mm} \mathrm{Ca}$.

\section{Discussion}

The results in this and the following paper confirm and extend the observations of Krishtal et al. (1983) showing that a subset of vertebrate sensory neurons possess a cation-selective conductance that is activated by micromolar concentrations of external ATP. The basic properties of the conductance-including rapid kinetics, superlinear concentration-response relationship at low [ATP], current-voltage relationship, and unitary current sizes - are quite similar in DRG neurons from rats and bullfrogs, suggesting the existence of very similar channels in the 2 species.

\section{Concentration-response}

In both bullfrog and rat neurons, the superlinearity of current versus [ATP] at low ATP concentrations suggests that more than one ATP molecule must bind in order for a channel to open. In determining the stoichiometry of a ligand: receptor reaction, it is ideal to study ligand concentrations that are very low (less than a percent or so of the half-maximal concentration), where current should increase with the $n$th power of the ligand concentration if $n$ molecules of ligand must bind in order to activate the receptor. It was not possible to study such low concentrations of ATP in the present work because the currents were too small; the lowest ATP concentrations for which cur-

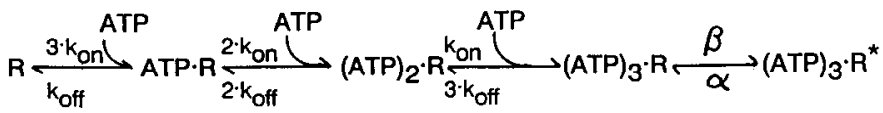

$$
\begin{aligned}
& k_{o n}=1.2 \times 10^{7} \mathrm{M}^{-1} \mathrm{~s}^{-1} \\
& k_{\text {off }}=4 \mathrm{~s}^{-1} \\
& B / \alpha=1 / 4
\end{aligned}
$$

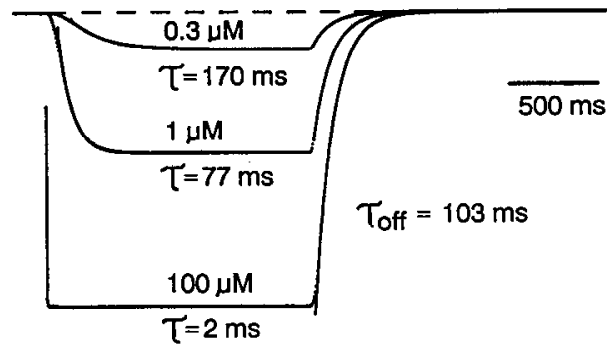

Figure 9. Kinetic model for ATP activation of channels. The kinetic scheme corresponds to activation of the channel by binding of ATP to 3 identical, noninteracting binding sites. Even with all 3 binding sites occupied, the channel is hypothesized to spend only a fraction of its time in the open state (denoted by the asterisk). It is assumed that the rate constants $\alpha$ and $\beta$ are large compared with the others (see next paper), so that states $(A T P)_{3} R$ and (ATP) $)_{3} R^{*}$ are in equilibrium during relaxation of macroscopic current. Simulations were performed by setting up equations for the entry and exit of channels in each state and integrating the equations numerically. To take into account the time course of solution changes, it was assumed that the ATP concentration changed with a time constant of $10 \mathrm{msec}$ during both application and removal (see Fig. $7 B$ ). The rate constants $k_{\text {on }}$ and $k_{\text {off }}$ were chosen so that the simulations mimicked the kinetics seen in the bullfrog cells whose results are shown in Figures 6 and 7. Shown are the simulated occupancy of the open state (discrete points), superimposed by a single exponential (plus a constant) obtained by a least-squares fit to the final $70 \%$ or so of the rise or fall of the current (solid lines).

rents could be accurately measured were $0.3-1 \mu \mathrm{M}$, concentrations that are typically $10-50 \%$ of the half-maximal [ATP]. In this concentration range, the increase of current with ligand concentration is expected to be less steep than the $n$th power, with the exact steepness dependent on the concentrations used (relative to the half-maximal concentration) and on whether the binding of ligand molecules is cooperative. The cell in Figure 4, which showed a 7-fold increase in current for a doubling in ATP from 0.6 to $1.2 \mu \mathrm{M}$, had both a particularly low sensitivity to ATP (concentration for half-maximal current $>10 \mu \mathrm{M}$ ) and a particularly large ATP-activated current, both conditions that would favor detection of a maximal degree of steepness in the current versus [ATP] relationship. Based on this cell, it seems reasonable to suppose that the stoichiometry of binding is at least 3:1. In other cells, doubling the ATP concentration in the range $0.3-1.2 \mu \mathrm{M}$ produced only 2.5 - to 4.5 -fold increases in current, but these increases are also consistent with 3:1 binding (see Fig. 5) given that the ATP concentrations are higher relative to the typical half-maximal concentration of $3 \mu \mathrm{M}$ or so. The concentration-response relationship in the range of 0.3-1.2 $\mu \mathrm{M}$ ATP was slightly less steep in rat cells than in bullfrog cells but, since desensitization in rat neurons makes it more difficult to compare currents at different concentrations, it is hard to know if there is a real difference. The simplest hypothesis consistent with the data in both species is that 3 ATP molecules must bind in order to activate a channel; furthermore, the concentration- 
A

B

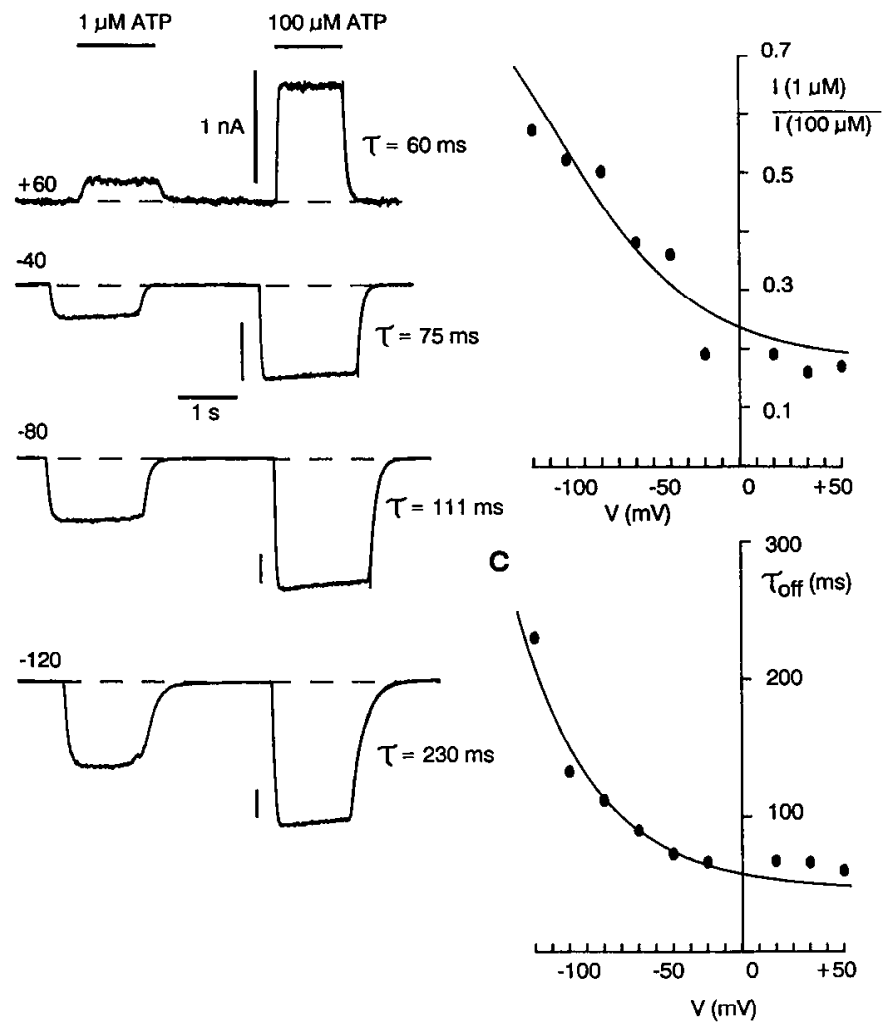

Figure 10. Voltage dependence of ATP-elicited current in a bullfrog DRG neuron. $A$, Currents in response to sequential application of 1 and $100 \mu \mathrm{M}$ ATP at the indicated membrane potentials. Note the different scaling of the current records; the current calibration bar in each trace corresponds to $1 \mathrm{nA}$. Superimposed on the experimental traces are smooth exponential curves with the indicated time constants, fit to the deactivation of current following removal of $100 \mu \mathrm{M}$ ATP. $B$, The ratio of current elicited by $1 \mu \mathrm{M}$ ATP to that elicited by $100 \mu \mathrm{M}$ ATP, plotted as a function of membrane potential. The smooth curve is the ratio predicted from the model in Figure 9 assuming that $k_{\mathrm{on}}$ is $10^{7} \mathrm{M}^{-1} \mathrm{sec}^{-1}$ (independent of voltage) and that $k_{\text {off }}$ varies with voltage according to $k_{\text {off }}=1 /\{0.11+0.055[\exp ((-32-\mathrm{V}) / 45)]\} \mathrm{sec}^{-1}$. This function is derived from the smooth curve fit to the data in $C$, using the relation $k_{\text {off }}$ $=1 /\left\{3 \tau_{\text {off }}[\alpha /(\alpha+\beta)]\right\}$. The current activated at each voltage by 1 and $100 \mu \mathrm{M}$ ATP was calculated by the formula for the fraction of channels predicted to be in the open state: $G^{3}(\beta / \alpha) /\left\{1+3 G+G^{2}+G^{3}(1+\beta / \alpha)\right\}$, where $G=\operatorname{ATP}\left(K_{\text {on }} / k_{\text {off }}\right) C$. Time constant for decay of the current as a function of membrane potential. The smooth curve is an empirically determined function that approximates the experimental data, given by $46+23 \exp [(-32-\mathrm{V}) / 45]$. Cell K20D. Internal solution $\mathrm{Mg}$-free Cs-glutamate, external solution (in mM) $160 \mathrm{NaCl}_{1}, 2 \mathrm{CaCl}_{2}, 10 \mathrm{HEPES}(\mathrm{pH}$ 7.4 with $\mathrm{NaOH}$ ).

response curves at higher concentrations are much better fit by assuming independence of the $3 \mathrm{ATP}$ binding sites rather than positive cooperativity of binding.

The evidence for $>1: 1$ stoichiometry of ligand to receptor disagrees with the results of Krishtal et al. (1983), who obtained a dose-response curve for a rat neuron that could be well-fit by assuming 1:1 binding. The difference most plausibly arises from difficulties in accurate measurements in rat neurons due to the rapid desensitization.

\section{Kinetics}

The rapid kinetics of activation and deactivation of current make it seem likely that ATP receptors are coupled directly to channels, rather than acting through a second-messenger sys-
A $165 \mathrm{Na}, 2 \mathrm{Ca} \quad 165 \mathrm{Na}, 0.1 \mathrm{EDTA}$
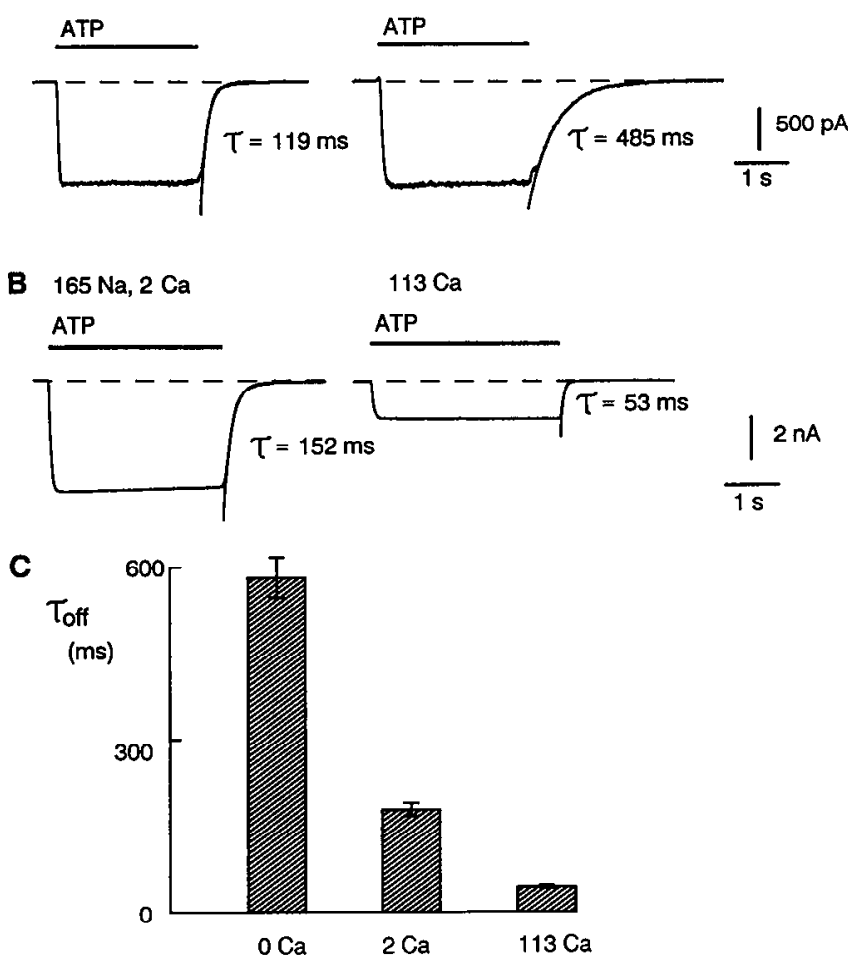

Figure 11. Dependence of the decay time constant on external Ca. $A$, Currents elicited in the same bullfrog DRG neuron by $100 \mu \mathrm{M}$ ATP applied at $-80 \mathrm{mV}$ with external solutions of (left) $165 \mathrm{~mm} \mathrm{Na}, 2 \mathrm{~mm}$ $\mathrm{CaCl}_{2}, 10$ HEPES (pH 7.4 with $\mathrm{NaOH}$ ) or (right) $165 \mathrm{~mm} \mathrm{NaCl}, 100$ $\mu \mathrm{M}$ EDTA, 10 HEPES (pH 7.4 with $\mathrm{NaOH}$ ). The decay of the current on removal of ATP is fit with a single exponential in each case. Cell $\mathrm{K} 05 \mathrm{G}, 24 \mu \mathrm{m}$. Internal solution Mg-free Cs glutamate. $B$, Records from a different cell in which the $165 \mathrm{Na}, 2 \mathrm{Ca}$ external solution was replaced by $110 \mathrm{mM} \mathrm{CaCl}_{2}, 10 \mathrm{~mm}$ HEPES (pH 7.4 with $\mathrm{CaOH}$ ). Cell K05F, 37 $\mu \mathrm{m}$. Internal solution $\mathrm{Mg}$-free $\mathrm{Cs}$-glutamate. $C$, Collected values for the decay time constant following removal of $100 \mu \mathrm{M}$ ATP at $-80 \mathrm{mV}$. Values are (mean $\perp \mathrm{SEM}): 0 \mathrm{Ca}, 580 \pm 36(n-6) ; 2 \mathrm{Ca}, 178 \pm 14(n$ $=12) ; 113 \mathrm{Ca}, 45 \pm 3(n=9)$.

tem. The kinetics of activation and recovery are much faster than for channels known to be controlled by second messengers. For example, the action of adrenaline or isoproterenol on cardiac Ca current, a process mediated by cAMP, takes many seconds to reach completion and to reverse. Even the activation of cardiac $\mathrm{K}$ channels by muscarinic ACh receptors, which is mediated by $\mathrm{G}$ proteins (see Logothetis et al., 1987; Kirsch et al., 1988) presumably acting over small distances, is quite a bit slower, with a decay time constant of several seconds (D. D. Friel and B. P. Bean, unpublished observation).

The direct control of the channels by ATP binding is supported by the success of the model in Figure 9 in fitting the experimental data. The association rate of about $10^{7} \mathrm{M}^{-1} \mathrm{sec}^{-1}$ seems reasonable for specific binding to a receptor; it is in the range $\left(10^{6}-10^{8} \mathrm{M}^{-1} \mathrm{sec}^{-1}\right)$ typical for binding of substrates to enzymes that have substrate specificity (Eigen and Hammes, 1963). The maximum possible diffusion-limited rate would be higher, about $10^{8}-10^{9} \mathrm{M}^{-1} \mathrm{sec}^{-1}$. Since the ATP receptor shows a high degree of specificity (Krishtal et al., 1989) for ATP over related molecules, a reasonable interpretation is that only a few percent of ATP molecules colliding with a receptor have the proper orientation to allow binding. 
The concentration of ATP at the surface of the membrane may be lower than in the bulk external solution, in which case the $k_{\text {on }}$ value of $10^{7} \mathrm{M}^{-1} \mathrm{sec}^{-1}$ (calculated from bulk ATP concentrations) is an underestimate. Most excitable cells probably have a negative surface potential arising from an excess of negatively charged groups (see McLaughlin, 1977; Hille, 1984). Such a surface potential would reduce the surface concentration of a negatively charged complex like ATP $\mathrm{Mg}^{2-}$ (the predominant form of ATP in a physiological saline solution) by a factor of $\exp (-2 F \psi / R F)$ compared with the bulk solution, where $\psi$ is the surface potential. Even a relatively modest surface potential of $-30 \mathrm{mV}$ would reduce surface ATP. $\mathrm{Mg}^{2-}$ by a factor of about 10. Some of the variability in ATP's potency from cell to cell could be due to different surface potentials near the ATP receptors.

It is impossible to completely rule out a second-messenger system on kinetic grounds. However, it can be said that any such pathway must be capable of being activated to completion with a time constant of $8 \mathrm{msec}$ and deactivated with a time constant as small as $35 \mathrm{msec}$ (in rats) and that such rates are faster than those so far demonstrated for second-messenger control of channels. It seems unlikely that phosphorylation-dephosphorylation reactions are involved in receptor-channel coupling because (besides the rapid kinetics) most experiments were done without ATP present in the internal solution and the ATP-activated current was present (and with unchanged kinetics) for more than an hour. The ability of ATP to activate channels in cell-free patches of membrane, reported in the next paper (see also Krishtal et al., 1988a), is also consistent with direct gating of channels.

\section{Comparison with ATP-activated channels in other excitable cells}

There are broad similarities between the ATP-activated channels in sensory neurons and ATP-activated channels found in a variety of other excitable cells, including smooth muscle from rabbit ear artery (Benham and Tsien, 1987; Benham et al., 1987), vas deferens smooth muscle (Nakazawa and Matsuki, 1987; Fricl, 1988), cardiac atrial cells (Friel and Bean, 1988), and cultured chick skeletal muscle (Hume and Honig, 1988). In all cases ATP activates a cation-permeable current that reverses near $0 \mathrm{mV}$.

There are clear differences in the concentration dependence of ATP action in the various cells. The potency of ATP action on sensory neurons described by Krishtal et al. (1983) and in this paper, with a $K_{1 / 2}$ of $1-10 \mu \mathrm{M}$, is similar to the potency of ATP in activating current in vas deferens smooth muscle cells, $K_{1 / 2} \sim 5 \mu \mathrm{M}$ (Friel, 1988), but substantially greater than that in cardiac atrial cells, with a $K_{1 / 2}$ of about $50 \mu \mathrm{M}$ (Friel and Bean, 1988). ATP action on vascular smooth muscle cells may be even more potent than on sensory neurons, since $10 \mathrm{nM}$ ATP can activate sizable currents in ear artery cells (Benham and Tsien, 1987; Benham et al., 1987; Bean and Friel, 1989); however, a detailed study of concentration dependence has not yet been made.

In all cases so far studied, there is evidence that multiple ATP molecules must bind in order to activate current. However, in vas deferens smooth muscle (Friel, 1988) and cardiac atrial cells (Friel and Bean, 1988), dose-response curves were best fit by assuming 2:1 binding and a high degree of positive cooperativity, in contrast to the $3: 1$ binding without positive cooperativity that provided the best fits to the data from sensory neurons.
The kinetics of ATP action have not yet been studied in detail in other cell types. However, in all cases the rise and fall of ATP-activated current may be equally fast as in sensory neurons. As in sensory neurons, the current activated in vas deferens smooth muscle cells by high ATP concentrations reaches a peak in less than $50 \mathrm{msec}$ (Bean and Friel, 1989).

\section{Comparison with other receptor-operated channels}

Both nicotinic $\mathrm{ACh}$ receptor channels and $\mathrm{GABA}_{\Lambda}$ receptor channels appear to require the binding of 2 agonist molecules in order to open (Dionne et al., 1978; Bormann and Clapham, 1985; Chabala et al., 1986; Colquhoun and Ogden, 1988). Thus, while sharing the need for multiple molecules of agonist to bind, ATP-activated channels in sensory neurons have a different stoichiometry, requiring the binding of (at least) 3 molecules of agonist. Relative to other nonpeptide transmitters that open channels, ATP acts at low concentrations. The typical $K_{1 / 2}$ of $0.5-5 \mu \mathrm{M}$ is about 5-10 times smaller than for ACh activation of end-plate channels (Colquhoun and Ogden, 1988) and is also smaller than for GABA (Akaike et al., 1986), glycine (Krishtal et al., 1988b), or excitatory amino acid activation of channels (Kiskin et al., 1986). This comparison strengthens the idea that ATP acts on a specific, sclective receptor, as is also implied by the high degree of ligand specificity found by Krishtal et al. (1989).

There are especially strong similarities between the ATP-activated channels in sensory neurons and another type of nucleotide-activated channel: cGMP-activated channels in mammalian photoreceptors. cGMP-activated channels also require multiple ligand binding and have a stoichiometry of 3:1 for channel activation (Fesenko et al., 1985; Haynes et al., 1986; Zimmerman and Baylor, 1986; Matthews and Watanabe, 1988). However, unlike ATP-activated channels, the binding of ligand molecules is apparently highly cooperative in cGMP-activated channels. As will be described in the next paper, the singlechannel currents in the 2 types of channels are also similar. Important differences are that the CGMP-activated channels are activated by agonist molecules on the cytoplasmic side of the membrane and that they show little or no desensitization.

\section{References}

Akaike, N., M. Inoue, and O. A. Krishtal (1986) "Concentrationclamp" study of $\gamma$-aminobutyric acid-induced chloride current in frog sensory neurones. J. Physiol. (Lond.) 379: 171-185.

Bean, B. P., and D. D. Friel (1989) ATP-activated channels in excitable cells. In Ion Channels, Vol. II, T. Narahashi, ed., pp. 169-203, Plenum, New York (in press).

Bean, B. P., C. A. Williams, and P. W. Ceelen (1990) ATP-activated channels in rat and bullfrog sensory neurons: Current-voltage relationship and single-channel currents. J. Neurosci. 10: 11-19.

Benham, C. D., and R. W. Tsien (1987) A novel receptor-operated $\mathrm{Ca}^{2+}$-permeable channel activated by ATP in smooth muscle. Nature 328: 275-278.

Benham, C. D., T. B. Bolton, N. G. Byrne, and W. A. Large (1987) Action of externally applied adenosine triphosphate on single smooth muscle cells from rabbit ear artery. J. Physiol. (Lond.) 387: 473-488.

Bormann, J., and D. E. Clapham (1985) gamma-Aminobutyric acid receptor channels in adrenal chromaffin cells: A patch clamp study. Proc. Natl. Acad. Sci. USA 82: 2168-2172.

Burnstock, G. (1979) Past and current evidence for the purinergic nerve hypothesis. In Physiological and Regulatory Functions of Adenosine and Adenine Nucleotides, H. P. Baer and G. I. Drummond, eds. pp. 3-32, Raven, New York.

Chabala, L. A. M. Gurney, and H. A. Lester (1986) Dose-response of acetylcholine receptor channels opened by a flash-activated agonist in voltage-clamped rat myoballs. J. Physiol. (Lond.) 371: 407-433. 
Colquhoun, D., and D. C. Ogden (1988) Activation of ion channels in the frog end-plate by high concentrations of acetylcholine. J. Physiol. (Lond.) 395: 131-159.

Dionne, V. E., J. H. Steinbach, and C. F. Stevens (1978) An analysis of the dose-response relationships at voltage-clamped frog neuromuscular junctions. J. Physiol, (Lond.) 281: 421-444.

Eigen, M., and G. G. Hammes (1963) Elementary steps in enzyme reactions. Adv. Enzymol. 25: 1-38.

Fesenko, E. E., S. S. Kolesnikov, and A. L. Lyubarsky (1985) Induction by cyclic GMP of cationic conductance in plasma membrane of rod outer segment. Nature 313: 310-313.

Friel, D. D. (1988) An ATP-sensitive conductance in single smooth muscle cells from the rat vas deferens. J. Physiol. (Lond.) 401: 361380 .

Friel, D. D., and B. P. Bean (1988) Two ATP-activated conductances in bullfrog atrial cells. J. Gen. Physiol. 91: 1-27.

Fyffe, R. W., and E. K. Perl (1984) Is ATP a central synaptic mediator for certain primary afferent fibers from mammalian skin? Proc. Natl. Acad. Sci. USA 81: 6890-6893.

Gordon, L. (1986) Extracellular ATP: Effects, sources, and fate. Biochem. J. 233: 309-319.

Hamill, O., A. Marty, E. Neher, B. Sakmann, and F. J. Sigworth (1981) Improved patch-clamp techniques for high-resolution current recording from cells and cell-free membrane patches. Pfluegers Arch 391: 85-100.

Haynes, L. W., A. R. Kay, and K.-W. Yau (1986) Single cyclic GMPactivated channel activity in excised patches of rod outer segment membrane. Nature 321: 66-70.

Hille, B. (1984) Ionic Channels of Excitable Membranes, pp. 316326, Sinauer Associates, Sunderland, MA.

Hume, R. I., and M. G. Honig (1986) Excitatory action of ATP on embryonic chick muscle. J. Neurosci. 6: 681-690.

Igusa, Y. (1989) Adenosine 5'-triphosphate activates acetylcholine receptor channels in cultured Xenopus myotomal muscle cells. J. Physiol. (Lond.) 405: 169-185.

Jahr, C. E., and T. M. Jessell (1983) ATP excites a subpopulation of rat dorsal horn neurons. Nature 304: 730-733.

Kirsch, G. E., A. Yatani, J. Codina, L. Birnbaumer, and A. M. Brown (1988) $\alpha$-Subunit of $G_{k}$ activates atrial $K^{+}$channel of chick, rat, and guinea pig. Am. J. Physiol. 254: H1200-1205.

Kiskin, N. I., O. A. Krishtal, and A. Ya. Tsydrenko (1986) Excitatory amino acid receptors in hippocampal neurons: Kainate fails to desensitize them. Neurosci. Lett. 63: 225-230.

Kolb, H.-A., and M. J. O. Wakelam (1983) Transmitter-like action of ATP on patched membranes of cultured myoblasts and myotubes. Nature 303: 621-623.
Krishtal, O. A., and V. I. Pidoplichko (1980) A receptor for protons in the nerve cell membrane. Neuroscience 5: 2325-2327.

Krishtal, O. A., S. M. Marchenko, and V. I. Pidoplichko (1983) Receptor for ATP in the membrane of mammalian sensory neurones. Neurosci. Lett. 35: 41-45.

Krishtal, O. A., S. M. Marchenko, and A. G. Obukhov (1988a) Cationic channels activated by extracellular ATP in rat sensory neurons. Neuroscience 27: 995-1000.

Krishtal, O. A., Y. V. Osipchuk, and S. V. Vrublevsky (1988b) Properties of glycine-activated conductances in rat brain neurones. Neurosci. Lett. 84: 271-276.

Krishtal, O. A., S. M. Marchenko, A. G. Obukhov, and T. M. Volkova (1989) Receptors for ATP in rat sensory neurons: The structurefunction relationship for ligands. Br. J. Pharmacol. 95: 1057-1062.

Logothetis, D. E., Y. Kurachi, J. Galper, E. J. Neer, and D. E. Clapham (1987) The subunits of GTP-binding proteins activate the muscarinic $\mathrm{K}$ channel in heart. Nature 325: 321-326.

Matthews, G., and S.-I. Watanabe (1988) Activation of single ion channels from toad rod inner segments by cyclic GMP: Concentration-dependence. J. Physiol. (Lond.) 403: 389-405.

McLaughlin, S. (1977) Electrostatic potentials at membrane-solution interfaces. Curr. Top. Membr. Trans. 9: 71-144.

Nakazawa, K., and N. Matsuki (1987) Adenosine triphosphate-activated inward current of isolated smooth muscle cells from rat vas deferens. Pfluegers Arch. 409: 644-646.

Salt, T. E., and R. G. Hill (1983) Excitation of single sensory neurones in the rat caudal trigeminal nucleus by iontophoretically applied adenosine 5'-triphosphate. Neurosci. Lett. 35: 53-57.

Sneddon, P., and G. Burnstock (1984) Inhibition of excitatory junction potentials in guinea pig vas deferens by $\alpha, \beta$-methylene ATP: Further evidence for ATP and noradrenaline as cotransmitters. Eur. J. Pharmacol. 100: 85-90.

Sneddon, P., and D. P. Westfall (1984) Pharmacological evidence that adenosine triphosphate and noradrenaline are cotransmitters in the guinea-pig vas deferens. J. Physiol. (Lond.) 347: 561-580.

Sneddon, P., D. P. Westfall, and J. S. Fedan (1982) Cotransmitters in the motor nerves of the guinea-pig vas deferens: Electrophysiological evidence. Science 218: 693-695.

Stone, T. W. (1981) Physiological roles for adenosine and adenosine 5 -triphosphate in the nervous system. Neuroscience $6: 523-555$.

$\mathrm{Su}, \mathrm{C}$. (1983) Purinergic neurotransmission and neuromodulation. Annu. Rev. Pharmacol. Toxicol. 23: 397-411.

Zimmerman, A. L., and D. A. Baylor (1986) Cyclic GMP-sensitive conductance of retinal rods consists of aqueous pores. Nature 321: 70-72. 